\title{
A POLÍTICA EDUCATIVA COLONIAL E A DISPUTA DAS MISSÕES CATÓLICAS E PROTESTANTES EM ANGOLA (SÉCULOS XIX-XX) $^{1}$
}

\section{Giselda Brito Silva}

Entre o final do XIX e ao longo do século XX, apenas com relativa exceção nos momentos da I República, o Estado português manteve um histórico colonial atrelado ao catolicismo nacional da Metrópole orientando o colonialismo em África. Nestes espaços coloniais, contudo, estas relações foram bem complicadas, tendo os missionários católicos portugueses que disputar o espaço colonial africano com católicos estrangeiros e protestantes.

Em Angola, por exemplo, tanto as missões católicas estrangeiras como as protestantes encontraram espaços abertos para implantar suas missões $e$ atuar no campo da orientação cristã e na chamada civilização do indígena, principalmente em regiões ainda não exploradas pelos portugueses, ou onde as missões católicas portuguesas não atendiam à demanda, causando grandes desconfortos nas autoridades portuguesas e na Igreja católica de Portugal, particularmente em relação às missões protestantes.

Em geral, a penetração de outras missões no espaço colonial português ocorria em decorrência das fragilidades político-econômicas de Portugal perante as demais nações imperialistas e seus interesses nas possessões portuguesas em África. Em finais do XIX, por determinações da Conferência de Berlim (1884-1885) e de Bruxelas (1889-1890), onde Portugal foi regulado para atuar na foz do rio Congo, as demais nações lançaram-se na corrida ao continente africano e estabeleceram o início de uma nova ação missionária. Assim, depois das Conferências, as missões passaram a ter um "direito internacional" que protegia os missionários e suas atividades, dando a eles a liberdade de atuar no espaço colonial africano. No caso das missões das colônias portuguesas, três documentos fundamentavam suas ações: o Acto Geral de Berlim de 1885, o Acto Geral de Bruxelas de 1890 e o Tratado Luso-Britânico de 1891. O Direito Internacional das Missões, que previa a liberdade de ação das missões, passou a regular as atividades missionárias e estabeleceu as relações império-missões, tornando-se uma proteção para a ação dos missionários pelos seus governos através da chamada "diplomacia missionária"

Desta forma, depois das Conferências de Berlim e Bruxelas, Portugal foi obrigado a permitir a circulação de membros da integração internacional da política imperial

${ }^{1} \mathrm{O}$ artigo é resultado do Projeto de Pesquisa intitulado "A colonização na África no século XX: as práticas discursivas e educativas dos doutrinadores do Império Português", realizado com apoio do CNPq (Processo $n^{\circ} 471129 / 2014-3$ ).

${ }^{2}$ Doutora em História pela Universidade Federal de Pernambuco. Realizou estágio pós-doutoral na área de História no Instituto de Ciências Sociais da Universidade de Lisboa entre 2011 e 2012. Professora Associada do Departamento e do Programa de Pós-Graduação em História da Universidade Federal Rural de Pernambuco. E-Mails: <giselda.silva@ufrpe.br>e < gibrs@uol.com.br>.

${ }^{3}$ DORES, Hugo Gonçalves. A missão da República: política, religião e o império colonial português (1910-1926). Lisboa: Edições 70, 2015, p. 1-52. 
europeia para a dita promoção da civilização nas colônias em África, incluindo as sociedades missionárias protestantes e católicas estrangeiras, que praticavam $e$ defendiam outras políticas educativas, cristãs e civilizatórias para os nativos. As interferências e interpenetrações missionárias de outras nações no espaço colonial português ganhavam mais legitimidade ainda com as críticas que circulavam sobre a política colonial portuguesa em África, particularmente em torno da insistência do uso do trabalho forçado dos nativos, depois de sua proibição pelo tratado das nações ${ }^{4}$.

De acordo com os relatórios de autoridades portuguesas, alguns missionários protestantes se juntavam aos críticos da política colonial portuguesa, denunciando o colonialismo português pelas suas práticas exploratórias do trabalho forçado dos nativos, inclusive indispondo os nativos contra os portugueses. Em 1897, por exemplo, William Clayton Pickersgill - representante da London Missonary Society havia denunciado a existência de um "sistema de serviçais' em Angola e São Tomé e Príncipe, no qual a contratação era uma fachada que encobria a carência de liberdades individuais e laborais dos nativos [...]"5.

Outros missionários estrangeiros também enviavam seus relatórios contendo críticas ao projeto ocupacional, educacional e civilizatório de Portugal em contraposição ao proposto pelas nações para as colônias africanas. Portanto, a presença de missionários protestantes, e mesmo católicos estrangeiros, nas colônias portuguesas era uma preocupação constante para as autoridades portuguesas, especialmente porque em alguns espaços eles eram os únicos a ministrar alguma educação $e$ formação cristã entre os nativos, praticando ainda o ensinamento de sua língua nacional.

Para as autoridades portuguesas a ação de outras missões estrangeiras nas suas colônias africanas, portanto, representava um problema, não apenas porque significava o olhar vigilante e a penetração de outras nações no espaço colonial português, mas, principalmente, porque os missionários estrangeiros implementavam um tipo de educação para os nativos que ia de encontro à política educativa portuguesa projetada para suas colônias, mais em conformidade com seus interesses imperiais.

Para compreender melhor estas questões, vamos enveredar por alguns momentos emblemáticos em que estes interesses têm pontos em comum e pontos que se distanciam, considerando-se seus interesses no espaço colonial português. Vamos começar por compreender melhor o que vem a ser a Política Educativa colonial portuguesa (da I República ao Estado Novo) para em seguida estabelecer as posições $e$ atuação de missionários católicos nacionais e estrangeiros $e$ de protestantes em relação a esta política.

\footnotetext{
4 JERÓNIMO, Miguel Bandeira \& MONTEIRO, José Pedro. "O império do trabalho: Portugal, as dinâmicas do internacionalismo e os mundos coloniais". In: JERÓNIMO, Miguel Bandeira \& PINTO, António Costa (org.). Portugal e o fim do colonialismo: dimensões internacionais. Lisboa: Edições 70, 2014, p. 16-19.

${ }^{5}$ JERÓNIMO \& MONTEIRO, "O império do trabalho...", p. 23.
} 


\section{A política educativa colonial em Angola da I República}

A política educativa do colonialismo português para suas colônias tem na sua base duas concepções centrais: a) a imposição de uma cultura nacional portuguesa, e, b) a integração nos interesses políticos e econômicos de Portugal nas colônias. Para isso, seguiram um dos principais doutrinadores do império, António Enes, que é conhecido como um dos mentores do colonialismo português e definidor do papel das missões na educação e nacionalização dos africanos para o momento da I República, quando se implantou o ensino laico propagador da República. Em decorrência da carência de pessoal para assumir a educação laica nas colônias, os representantes da república tiveram que manter algumas missões religiosas ${ }^{6}$.

Com a implantação da ditadura, resultado do golpe de 28 de maio de 1926, Norton de Matos assume o alto comando de Angola e reforça as diretrizes do colonialismo português e da política educativa do novo regime, reafirmando as duas concepções de António Enes, porém, retomando o apoio e privilégio das missões católicas nacionais no império português, depois da restauração católica. Desta forma, às missões católicas seriam novamente entregues os destinos da educação dos nativos paralelamente à implantação do Estatuto do Indigenato, que passa a vigorar depois de 1926, cuja proposta significava na prática a exclusão sistemática de muitos nativos do acesso à educação formal, logo do acesso à condição de cidadania. (pp. 7-8)

De acordo com Pélissier $\mathrm{O}$ avanço das missões e da ocupação dos portugueses, no espaço hoje conhecido como Angola, não se deu de forma tranquila e pacífica. As missões atuaram paralelas às campanhas militares nas áreas mais resistentes de Angola, o que alimentava os projetos da política educativa colonial, levando as autoridades a investir cada vez mais no apoio da religião e da educação para minimizar a necessidade das campanhas militares e o uso das guerras contra os resistentes e revoltosos ${ }^{7}$. José Marques Guimarães reforça a posição de René Pélissier lembrando que o trabalho das missões, na cristianização e educação dos nativos, era inerente à questão da dominação colonial, porque,

[...] em face do violento antagonismo que caracteriza as relações entre a sociedade colonizadora e a sociedade colonizada [...] a dominação não pode manter-se apenas com base na força, tendo necessidade de recorrer a múltiplas formas de legitimação da sua hegemonia. Neste âmbito, a religião e a educação constituíram sempre instrumentos fundamentais de integração e subordinação dos africanos ao modelo social de dominação dos europeus, na óptica da rentabilidade máxima da relação colonial. ${ }^{8}$

\footnotetext{
${ }^{6}$ GUIMARÃES, José Marques. A política 'educativa' do colonialismo português em África: da I República ao Estado novo (1910-1974). Lisboa: Profedições, 2006, p. 7-8.

${ }^{7}$ PÉLISSIER, Réne. História das campanhas de Angola: resistências e revoltas (1845-1941) - vol. I. Lisboa: Editorial Estampa, 2013.

${ }^{8}$ GUIMARÃES, A política 'educativa'..., p. 10.
} 
De acordo com o projeto colonial, portanto, as práticas educativas das missões deveriam implementar um tipo de ensino que visasse a formação dos nativos em trabalhadores necessários para a ocupação e aproveitamento rentável das colônias. $\mathrm{Na}$ essência e na prática, tal ensino deveria ser pautado nas práticas de trabalho dos nativos e no ensinamento de uma nova cultura e de relações de trabalho, bem como no reordenamento da organização social e política interna, de modo a viabilizar a introdução de novas relações e hábitos culturais europeus.

Para fundamentar estas mudanças era preciso em princípio ensinar e oficializar a língua do colonizador em detrimento das línguas nativas, além de reforçar o ensino da concepção cristã, que já tinha sido plantada entre os reis do Congo português desde os séculos $\mathrm{XV}$ e $\mathrm{XVI}$, e que teria rendido muitos missionários nativos que puderam colaborar com o colonialismo, entre finais do século XIX e ao longo de todo o século $\mathrm{XX}$. Mesmo entre estes havia a compreensão dos limites impostos para os ensinamentos aos nativos, ainda que Portugal tenha expressado em alguns momentos uma preocupação com uma educação mais próxima da dos filhos dos colonos para os nativos, em particular na I República, por considerarem que a viabilidade do projeto colonial dependia de civilizar os nativos.

$\mathrm{Na}$ I República, Norton de Matos chegou a expressar sua preocupação com a educação dos nativos mais próxima daquela dada aos filhos dos colonos, como condição para os nativos serem chamados de civilizados no padrão do colonizador, $e$ mais coerente com as determinações das nações imperialistas e seus projetos de civilizar os povos colonizados. Com estes pensamentos, em 1912, e na condição de governador-geral de Angola, ele defendeu em seus relatórios ao Ministro das Colônias que "o indígena só renasceria para a nova vida colonial, quando a sua língua fosse o português e a sua instrução crescesse paralelamente à dos filhos dos colonos" ${ }^{9}$.

Assim, em 10 de abril de 1913, ele mandou um Projeto ao Ministro das Colônias com uma proposta de organização da instrução pública para Angola, cujo trecho abaixo é representativo da sua concepção de instrução e educação dos nativos, explicitando as determinações do trabalho e sua percepção de civilidade a ser destinada aos colonizados, para tornar a empresa colonial viável e rentável:

A grande massa dos pretos, quase completamente fechados pelas trevas de civilizações primitivas; um número limitado de pretos e mestiços, com uma rudimentar instrução, que apenas servia para os tirar da sua civilização sem os introduzir na nossa, e para foram homens sem carácter; um grupo cada vez maior, também, de pretos e mestiços, digno de toda a nossa consideração e elevando-se, graças quase exclusivamente ao seu esforço e vencendo mal-entendidas oposições, ao nível da nossa civilização.

Indispensável era, antes de mais, tomar as providências necessárias para não se produzirem mais pretos pseudoinstruídos e pseudo-civilizados, como os do segundo grupo da

\footnotetext{
${ }^{9}$ MATOS, Norton. Memórias e trabalhos da minha vida: obras completas do general Norton de Matos e seu tempo (1867-1955). Coimbra: Imprensa da Universidade de Coimbra, 2005, p. 219.
} 
minha classificação. Melhor seria deixar os pretos de Angola para sempre analfabetos, do que criar aquele híbrido degenerado a que se deu o nome de 'cambaquista', e cujas principais características são o desprezo pelo trabalho manual e a não sujeição [...] não vi e ainda não vejo hoje, outro meio de evitar o aparecimento de elementos demográficos desta natureza, que não seja a íntima ligação da instrução literária com a aprendizagem de artes e ofícios. Tem de ser esta base fundamental da instrução africana. Por essa razão o meu projecto de instrução, de 1913, estabelecia que tanto a instrução primária elementar, como a complementar e a superior abrangeriam o ensino de uma profissão manual, agrícola ou industrial, adequada ao sexo e às consequências da região. O sexo feminino receberia, além disso, ensino de trabalho de agulha e de economia doméstica.

[...]

Não arrancar os indigenas rapidamente do seu modo de viver, aos seus usos e costumes, e deligenciar fazê-los evolucionar, de dentro dos quadros da sua própria civilização, para uma civilização mais perfeita; a educação e a instrução da grande massa dos indígenas de Angola devia ser um dos meios de melhorar a sua condição social, e não um fim; a instrução meramente literária e o proselitismo, isolados $e$ como fins únicos a atingir, produzirão sempre os piores resultados nas populações indígenas; foram estes os princípios orientadores da minha política de instrução, parte integrante do meu propósito de fazer a grande transformação, de onde resultasse o novo indígena. ${ }^{10}$

O Projeto de instrução e educação de Norton de Matos, da I República, só receberia maior atenção no Estatuto Missionário de 1941, em seu artigo 68, aprovado pelo Decreto-lei n. 31.207, de 05 de abril de 1941, quando Salazar defenderia ideias de uma educação dos nativos mais próximas daquelas já defendidas por Norton de Matos, particularmente na instrução primária e nos cursos técnicos profissionais que se viu no Estado Novo para os nativos de Angola, ainda que estivessem muito aquém das definidas para os jovens da Metrópole e filhos dos colonos nas colônias ${ }^{11}$.

Retomando a concepção de Norton de Matos, aos tempos da I República, localizamos em suas memórias que o projeto não teria se efetivado devido a três pontos fundamentais: ausência de verbas, de professores e de escolas. Já que para ele, além daqueles que não tinham educação alguma, tornando-se inviável ao projeto colonial, ainda havia na colônia aqueles que já tinham recebido alguma educação, mas, que não passavam de um "grupo de negros, homens e mulheres, já longe das trevas do passado, cuja instrução deveria ser desenvolvida, para utilizá-los no

\footnotetext{
${ }^{10}$ MATOS, Memórias e trabalhos..., p. 219-221.

${ }^{11}$ GUIMARÃES, A política 'educativa'..., p. 15.
} 
exercício das funções públicas". E que ele identificava nas tarefas e cursos abaixo que deveriam ser implementados para fazer evoluir o desenvolvimento da colônia, sendo eles:

O professorado elementar, o estado menor dos serviços de Angola, os lugares de agrimensores, regentes agrícolas, maquinistas, telegrafistas, apontadores, pilotos e enfermeiros devem ser exercidos por naturais da província, brancos ou pretos, nela educados e instruídos, conhecedores das suas regiões, das línguas, usos costumes dos povos que as habitarem.

O mesmo deve dar-se para grande número de empregados de casas comerciais, das empresas agrícolas e industriais.

Foi tendo isto em vista, que no meu projecto de 1913 se criaram cursos de professores de ensino primário elementar, cursos de comércio, de regentes agrícolas coloniais, de maquinistas, de pilotagem, de apontadores de obras públicas, de mestres de obras, de agrimensores, de correios e telégrafos e de enfermagem. ${ }^{12}$

Na sequência de suas memórias também vamos encontrando críticas às missões que, segundo ele, apresentavam muitas precariedades, principalmente as missões laicas, que em razão da "mancebia [dos seus responsáveis] com mulher de cor, merece a sua organização o maior cuidado ao alto-comissariado. O que fui encontrar em Angola sobre as missões laicas para pouco ou nada servia"13.

Sobre as missões religiosas, Norton de Matos, ainda que representante da I República, reconhecia seus serviços, considerando "falta imperdoável não os aproveitar, não os chamar a colaborar com o Estado, para se realizar a transformação de Angola, que a Nação desejava". Enfatizando que, apesar da falta de apoio do Estado para

[...] a organização missionária cristã em exercício na província [...] nenhum acto pratiquei, nenhuma omissão houve da minha parte, que pudessem prejudicar ou perturbar, de leve que fosse, a liberdade evangelizadora dos missionários cristãos. Tudo fiz para a garantir plenamente. O que não podia deixar era criar estados no Estado, erguer ao lado do Estado português poderes iguais ou maior força ou influência, e desistir de fiscalizar a actividade de todos os organismos da província, cuja alta administração me pertencia. ${ }^{14}$

\footnotetext{
${ }^{12}$ MATOS, Memórias e trabalhos..., p. 219-221.

${ }^{13}$ MATOS, Memórias e trabalhos..., p. 232.

${ }^{14}$ MATOS, Memórias e trabalhos..., p. 232.
} 
O que em sua reflexão também servia para justificar Portugal perante o "Acto de Berlim" acerca do livre exercício proporcionado "a todos os cidadãos das potências signatárias ou daquelas que, sendo membros da Sociedade das Nações, venham a ser signatárias". E, neste sentido, continua, "os missionários terão o direito de entrar, de circular e de residir no território africano, com a faculdade de nele se estabelecerem para produzirem na sua obra religiosa" 15 .

Sobre a manutenção das missões estrangeiras, nas províncias portuguesas, Norton de Matos estabelecia que as potências deveriam proteger e favorecer, sem distinção de nacionalidade e de culto, as instituições e as empresas religiosas, científicas ou de caridade, criadas ou organizadas pelos cidadãos de nações membros da Sociedade das Nações, e que se dedicarem a "conduzir os indígenas pelo caminho do progresso $e$ da civilização" 16 .

Pelo que vimos acompanhando das concepções da política educativa colonial da I República, com Norton de Matos, a presença de missionários católicos foi aceita, desde que se regulasse sua autoridade e poder nas colônias e na Metrópole, considerando-se a separação da Igreja e do Estado na República Portuguesa ${ }^{17}$. Neste sentido, como também registra José Marques Guimarães, cabia às missões compreenderem seus limites de ação e de posições, conforme as determinações abaixo:

O predomínio das missões portuguesas relativamente às estrangeiras, quer do ponto de vista numérico quer em termos de eficiência; A prática obrigatória do ensino exclusivo da língua portuguesa; $O$ ensino preferencial de matérias $e$ profissões adequadas a cada um dos sexos, excluindo completamente o ensino literário, para além do rudimentar. ${ }^{18}$

Portanto, conforme vamos observando, as missões atuaram de certa forma sem as fiscalizações e controles prometidos, particularmente em áreas ainda não ocupadas pelos portugueses e nos espaços rurais, onde rareavam missões católicas e laicas nacionais, deixando-se os espaços do interior do planalto central e norte de Angola um campo aberto para a atuação de outras missões estrangeiras.

A implantação e atuação das missões católicas ou protestantes em Angola, contudo, não foi uma obra fácil e sem enfrentamentos com o poder nativo local, além dos limites impostos pela Metrópole e autoridades locais. De acordo com Lawrence W. Henderson, o território que hoje se conhece como Angola, até o último quartel do século XIX e primeiro do XX, ainda não era ocupado pelos portugueses. Portanto, eram áreas onde Portugal ainda não exercia domínio total na região do Congo, onde

\footnotetext{
${ }^{15}$ MATOS, Memórias e trabalhos..., p. 233.

${ }^{16}$ MATOS, Memórias e trabalhos..., p. 233.

${ }^{17}$ MATOS, Memórias e trabalhos..., p. 233.

${ }^{18}$ GUIMARÃES, A política 'educativa'..., p. 43.
} 
os reinos africanos ainda predominavam podendo decidirem a instalação ou não de missões ${ }^{19}$.

Em alguns espaços, os reis do Congo chegavam mesmo a exercer grande influência sobre as missões católicas e protestantes instaladas, a exemplo da missão de S. Salvador, que ficava na confederação Umbundu (no planalto de Benguela), embora de forma descentralizada. Alguns reis, a exemplo de Kwanyama, da zona mais meridional de Angola, também conseguiram frustrar o trabalho de missionários católicos e protestantes, com grande predomínio e preservação da cultura religiosa africana local ${ }^{20}$.

Por outro lado, os primeiros missionários deste momento do colonialismo de finais do XIX e começos do XX, tanto católicos como protestantes, vão identificar a religião nativa como fragilizada pela ausência de um texto escrito (a exemplo da bíblia cristã) e ausência de uma língua única comum, o que permitia aos missionários atuar entre um grupo e outro, apesar do poderio dos reis. Tais fragilidades teriam sido apontadas pelos missionários como o caminho certo por onde seria possível educar os nativos na cultura do colonizador e dentro do perfil do cristianismo ${ }^{21}$.

Daí uma das primeiras ações para educar os nativos no cristianismo deveria partir de um conhecimento das línguas e das religióes nativas a fim de preparar os missionários para atuar na obra da catequese, da educação e, consequentemente, na colonização. Algumas missões tiveram sucesso, outras fecharam $e$ fracassaram por uma série de dificuldades no contato e no cotidiano das missões. Os motivos estavam nas várias maneiras implementadas pelas diferentes missões e correntes cristãs que se implantaram em Angola, e que Lawrence Henderson procura mapear especificando a variação das Igrejas e atuação entre católicos e protestantes de acordo com as questões locais ${ }^{22}$.

Para Henderson a entrada de missionários católicos de outras nacionalidades e protestantes, em obediência à determinações da Conferência de Berlim de 1885, vinha em boa hora para suprir a ausência de missionários estrangeiros que esta Igreja enfrentava com a política da I República portuguesa. Ainda que tais entradas de missionários protestantes na possessão portuguesa preocupasse o Estado e a Igreja Católica nacional cujas relações estavam abaladas.

Conforme vamos observando na obra do Padre Lawrence Henderson, as Igrejas cristãs que atuaram na política educativa em Angola eram de várias vertentes. Entretanto, em sua percepção, apesar de momentos acirrados não houve tantos conflitos entre católicos e protestantes, em razão da necessidade de se unirem para construir o cristianismo entre os nativos, além das condições locais que exigiam uma relativa parceria entre os colonos nos enfrentamentos locais ${ }^{23}$.

Isto, contudo, não invalida que eles tinham momentos de fortes embates. Por outro lado, os embates se davam mais entre católicos e protestantes do que entre católicos nacionais e estrangeiros. Porque tanto os missionários católicos como as

\footnotetext{
${ }^{19}$ HENDERSON, Lawrence W. A Igreja em Angola: um rio com várias correntes. 2. ed. Lisboa: Editorial Além-Mar, 2013, p. 43.

${ }^{20}$ HENDERSON, A Igreja em Angola..., p. 43.

${ }^{21}$ HENDERSON, A Igreja em Angola..., p. 43.

${ }^{22}$ HENDERSON, A Igreja em Angola..., p. 43.

${ }^{23}$ HENDERSON, A Igreja em Angola..., p. 43.
} 
autoridades portuguesas não apreciavam o avanço $e$ crescimento da Igreja protestante em suas colônias. Os missionários protestantes, por sua vez, valiam-se da carência de missionários católicos em algumas regiões do interior de Angola e dos seus conflitos com o Estado republicano e, principalmente, dos conflitos das autoridades portuguesas com os chefes locais.

Nestes momentos as missões protestantes avançavam, tornando-se uma segunda opção de educação e evangelização pelo cristianismo em África, principalmente nos espaços onde os nativos estavam mais desconfiados ou descrentes dos missionários católicos, em decorrência de suas condutas com os nativos e por algumas promessas não cumpridas entre o XVI-XIX.

Também é no período que precede e envolve a I República que os reis e nativos vão percebendo os reais interesses da política educativa do colonialismo implementada nas missões católicas, onde também se ensinava a compreender as desapropriações de terras, as cobranças dos impostos e a utilização do trabalho forçado dos nativos, além de fazerem uso destas políticas, enquanto ensinavam $e$ civilizavam. Aos poucos as missões protestantes vão percebendo as condições favoráveis para sua penetração no espaço colonial português, muitas vezes, ganhando a preferência e a confiança local, o que vai gerando preocupações entre os missionários católicos nacionais e estrangeiros, já que representava o avanço da religião protestante na África, considerado um espaço com muitas almas a salvar e civilizar.

\section{As missões protestantes e o campo de disputa em Angola}

Desta forma, em 1900, a Igreja protestante já tinha um número relativo de missões em relação às católicas nacionais, considerando-se que o número de missões católicas estava nas mãos da Congregação do Espírito Santo, de origem francesa ${ }^{24}$. É através da atuação dos missionários espiritanos que os católicos conseguiram ficar na frente das missões protestantes. Em torno da implantação da I República, já existiam cerca de 42 estações missionárias em Angola, sendo 25 católicas e 16 protestantes. O que significava um avanço importante para os protestantes em Angola. Entre as católicas a que mais avançava era a dos Missionários do Espírito Santo, que haviam chegado em Angola em 1866 e construíram dezenas de missões, hospitais, colégios, escolas, Igrejas. Contudo, a implantação da República trouxera muitos problemas à Igreja católica e mais liberdade aos protestantes ${ }^{25}$.

Na I República, os missionários protestantes penetraram atuaram no campo da educação, assistencialismo e evangelização. Contudo, desviaram-se da política colonial portuguesa, cuja função dos missionários era formar os nativos, pela educação e cristandade, para a viabilidade do colonialismo português, e enveredaram por práticas de orientação de resistências e revoltas. Membros da memória da resistência colonial, já nos primeiros anos da ditadura salazarista, faz referência à participação dos protestantes na educação, mas também que eles orientavam sobre

\footnotetext{
${ }^{24}$ NEVES, Tony. "As Igrejas e o nacionalismo em Angola". Revista Lusófona de Ciência das Religiões, ano VI, 2007, n. 13/ 14, p. 511-526.

${ }^{25}$ HENDERSON, A Igreja em Angola..., p. 124.
} 
os problemas locais, em contraposição às práticas das missões católicas que, segundo os membros da resistência, eram muito mais cumpridores das determinações da política educativa colonial:

As missões protestantes têm prestado ao Negro uma assistência incomparavelmente maior do que as Católicas, desde a seriedade com que ministravam o ensino, à preocupação com que estudam alguns problemas locais e os pretendem resolver, não só em questões de assistência médica, como na maneira relativamente sã de prepararem os seus pupilos. Não usufruem quaisquer subsídios do Estado, que alias lhes põe certas dificuldades, receando naturalmente pela soberania. [...] Em 1934, havia 45 missões protestantes. Ignoramos o número de professores e alunos. ${ }^{26}$

Entretanto, apesar destas observações, os protestantes atuavam em Portugal e nas suas possessões enfrentando muitos conflitos, provocações e intolerâncias de pessoas defensoras da fé católica e membros da Igreja em Portugal, apesar deles terem adquirido proteção judicial na Monarquia Constitucional depois até 1910. Até 1851, diz-se, contudo, que as condições dos protestantes em Portugal não eram de conforto, enfrentando muitas pressões:

De tolerância a partir da consolidação da Monarquia Constitucional em 1851. Esta tolerância diz respeito ao modo como o ordenamento jurídico era interpretado pelas autoridades do Estado. Mas essa tolerância não era tão fácil em certos ambientes sociais e geográficos onde os protestantes tinham de inserir-se e onde enfrentaram algumas vezes fortes pressões de hostilidade. [...] O Código de 1867 permitiu que os protestantes constituíssem as suas congregações e mesmo que fossem fundadas em 1878 a primeira Igreja protestante, apesar dessas realidades não se enquadrarem bem no previsto na letra e no espírito da lei. ${ }^{27}$

Já no campo das práticas missionárias e educativas, eles teriam condições mais favoráveis de atuação em razão das dificuldades de sustentação e manutenção das missões católicas nas colônias africanas, particularmente em momentos de crise política, como o da invasão napoleônica, o que tornava o espaço de Angola um campo de disputa entre católicos e protestantes, ainda que missionários protestantes reconhecessem o trabalho de padres missionários católicos e vice-versa.

${ }^{26}$ LARA, Lúcio (Arquivo). "O Ensino em Angola (1954)". Cf. www.fmsoares.pt - CasaComum.org Documento: http://hdl.handle.net/11002/fms_dc_83571 (acesso, 2016-4-10).

${ }^{27}$ SANTOS, Luís Aguiar. "O protestantismo em Portugal (sécs. XIX e XX)". Revista Lusitanea Sacra, $2^{\mathrm{a}}$ Série, Tomo XVII, 2000, p. 44. 
David Livingstone, missionário protestante inglês e membro da Sociedade das Missões de Londres, por exemplo, é citado por Barnabé Tube por ter lutado contra o fim da escravidão, escrevendo livros denunciando as situações, através de viagens de exploração à África, mas, destacando as visitas a colégios dos padres jesuítas, que tinha se transformado em oficina para o ensino profissional, biblioteca e o convento de Luanda. Também teria elogiado o trabalho dos missionários católicos após ter visitado as ruinas da Catedral de S. Salvador, Mbanza Congo ${ }^{28}$.

Seguindo seus passos, o missionário Barnabé Tubi conta que havia outros estrangeiros que começaram a frequentar as colônias portuguesas, como jornalistas e missionários protestantes a serviço do rei Belga, Leopoldo II. Também surgiram franceses, ingleses, americanos e outros exploradores desta África que, naquele final do século XIX, passava a ser atenção de outras nações colonizadoras e de outras missões evangelizadoras ${ }^{29}$.

Os primeiros protestantes chegaram em S. Salvador em 1878, enviados pela Sociedade Missionária Baptista de Londres (BMS). Nos primeiros momentos, os missionários não sabiam falar kicongo, nem português, tendo que realizar momentos religiosos em língua inglesa, daí enfrentaram dificuldades só vindo a batizar o primeiro convertido depois de seis anos da missão. A partir daí converteram outros que assumiram as traduções, a exemplo de Nlemvo e Nekaka, que contribuiram para a implantação da Igreja protestante entre sua gente $e^{30}$.

As missões protestantes, contudo, tiveram dificuldades de se manter na imagem de missionários sedentários, principalmente, porque peregrinavam muito na região, sendo alvo de comentários dos angolanos, que os comparavam com os católicos, que tinham uma cultura de fixação bem maior. Paralelamente, ainda, tiveram que enfrentar a formação da missão católica de S. Salvador. É importante destacar que, na região do Congo, tanto os missionários católicos como os protestantes, mantinham um contato direto com o poder local do rei que detinha um poder centralizado em Angola. Da parte da Monarquia portuguesa importava, principalmente, contribuírem para civilizar os nativos e evitar que as colônias fossem perdidas por Portugal.

A missão protestante em Angola, chegou a ensinar escravos a ler e escrever, como Nekaka, que fora vendido como escravo a outro zombo. Contudo, depois de lhes prestar o serviço, passa a utilizar o trabalho de Nekaka, que trabalhava pedreiro, passando a construção da Igreja e outras casas da missão de S. Salvador, além de pregador itinerante de vilas no norte de Angola, onde também construiu as primeiras instalações definitivas, fora de S. Salvador, além de atuar em traduções de hinos para o hinário congo ${ }^{31}$.

Os protestantes metodistas também atuaram em Angola, no ano de 1885, liderados pelo bispo Willian Taylor, juntamente com outras famílias que the acompanhavam, entre eles um linguista que deixou vários escritos em kimbundu, como gramática e outros tratados da língua adaptados para a língua local. E, no

\footnotetext{
28 TUBI, Barnabé Lelo. As Missões Centenárias da Diocese de Cabinda (1873-1973). Lisboa: Universidade Católica Portuguesa, 1997, p. 32.

${ }^{29}$ TUBI, As Missões Centenárias..., p. 33.

${ }^{30}$ HENDERSON, A Igreja em Angola..., p. 96.

${ }^{31}$ HENDERSON, A Igreja em Angola..., p.99.
} 
campo do ensino, ministravam as aulas em português, mas, também ensinavam francês, inglês e alemão. A principal missão educativa e evangelizadora deste grupo era a de Quéssua na cidade de Malanje. Além dos batistas e metodistas, havia também os adventistas, que também tiveram uma atuação na área médica entre os nativos, além do campo de educação da língua e do cristianismo ${ }^{32}$.

Era comum a penetração das missões protestantes nas áreas rurais ${ }^{33}$, onde a presença de missões católicas era muito carente, havendo um campo mais aberto à penetração das missões protestantes. A Dondi era considerada "a casa mãe", de todas as missões protestantes que pertenciam à Junta Americana e Canadense de Angola. A ação deles se espalhou para outras regiões como Uma, Longongo, Vila Flor, Benfica, Chitata, Cassougue e Amboíva ${ }^{34}$.

As missões dos metodistas tinham como método educativo a implantação de atividades profissionais que também serviam para sustento da missão. Os alunos das missões pagavam seus estudos com milho e trabalhos. Através do trabalho de um linguista do grupo, conseguiram publicar uma gramática de kimbundu e traduzir o Evangelho de São João, contudo, ao se denominarem autossuficientes terminaram por ter dificuldades financeiras e a terem poucas conversões, já que os missionários gastavam mais tempo de trabalho nas fábricas de madeiras e nas fazendas ${ }^{35}$.

Paralelamente, ao campo da catequese e educação para o trabalho, o outro campo de atuação dos missionários metodistas era a assistência médica, através da qual também orientavam da religião cristã com base nos ensinamentos de sua doutrina. Eles acreditavam que se deveria cultuar Deus através de um corpo saudável, já que um dos princípios da doutrina dos Adventistas do Sétimo Dia para as missões era estabelecer as bases para a importância conferida à saúde, segundo a qual

[...] os crentes devem reconhecer os seus corpos como templos do Espírito Santo e por isso devem vestir-se dum modo limpo, simples e digno. Além disso, devem, tanto no beber e no comer como em toda a sua conduta, moldar as suas vidas para se tornarem seguidores do Senhor, modestos e submissos. Assim os discípulos de Cristo serão levados a abster-se de todas as bebidas intoxicantes, do tabaco e dos

${ }^{32}$ SILVA NETO, Teresa José Adelina da. Contribuição à História da Educação e cultura de Angola: grupos nativos, colonização e a independência. Tese (Doutorado em Educação). Universidade Estadual de Campinas. Campinas, 2005, p. 117.

33 "Até meados do século XIX, a organização dos territórios ultramarinos não tinha um modelo único de administração. Cada colónia era gerida consoante às necessidades do governo português, incidindo a sua ação naquelas que maior lucro apresentava. África era pouco mais do que um centro de passagem das rotas índicas e por isso apenas o litoral oferecia vantagens aos interesses da metrópole". Cf. CARDOSO, Sara Alexandra Martins. As Cartilhas Coloniais de Augusto Casimiro e Pedro Muralha. Dissertação (Mestrado de Ensino de Português como Língua Segunda e Estrangeira). Universidade Nova de Lisboa. Lisboa, 2013.

${ }^{34}$ SILVA NETO, Contribuição à História da Educação..., p. 117.

${ }^{35}$ HENDERSON, A Igreja em Angola..., p. 116. 
outros narcóticos e a evitar todo e qualquer hábito que profane o corpo e a alma. ${ }^{36}$

Para fundamentar suas práticas no campo do tratamento do corpo, os metodistas investiram na construção de hospitais e em Redes de Assistência Médica da Missão Suíça, considerada a segunda maior rede protestante de assistência médica, sob a orientação do Dr. Rudolphe Bréchet e da sua mulher Annie, em 1943, situada na missão Kalumkembe, onde construíram um hospital que atendia doentes de toda natureza, entre leprosos e tuberculosos ${ }^{37}$.

\section{As questões locais e as disputas das missões católicas e protestantes em Angola}

Ao longo da I República, portanto, as missões católicas e protestantes atuavam paralelamente, mas já sem a predominância dos católicos que enfrentaram muitas dificuldades com o governo republicano, que expulsou os jesuítas de Portugal e de suas colônias. E, ainda que alguns tenham permanecido nas colônias ultramarinas, eles ficaram por sua conta e risco, tendo muitas dificuldades com as resistências locais $e$ a falta de apoio financeiro e até militar. Com a ascensão do salazarismo é que esta situação vai se inverter, conforme veremos mais adiante.

Na I República, contudo, ocorre um clima favorável à expansão das missões estrangeiras e protestantes no interior de Angola. Mas, à medida que eles avançavam, causavam cada vez mais desconfianças entre os portugueses na colônia $e$ na Metrópole, que vão observando suas influências na formação educativa dos nativos e inclusive suas participações nas revoltas dos nativos contra o colonialismo português, ensinando-lhes outras línguas e prestando informações sobre o colonialismo português que eram consideradas estimuladoras das resistências ${ }^{38}$.

Um dos grupos de missionários protestantes que mais causaram grande desconforto entre os missionários católicos, e até desconfiança entre os chefes locais, foram os de nacionalidade alemã. Mas, com o tempo, eles foram conquistando o apoio local e passaram até a serem considerados aqueles que terminavam recebendo o apoio dos chefes locais, que consideravam sua política educativa proveitosa e ainda os ajudavam a fazer frente aos portugueses. Foi com autorização destes chefes que eles conseguiram abrir a quarta missão em Omatemba, com apoio e trabalho dos jovens locais. Enquanto isso, a missão católica do padre Lecomte teve que se mudar para outro espaço, por conta de conflitos que teve enfrentava com nativos ${ }^{39}$.

A penetração de missionários protestantes estrangeiros para o interior do território de uma colônia portuguesa colocava em risco a própria legitimidade do império de Portugal. É importante destacar que, em 1845-1848, os limites geopolíticos do que hoje conhecemos como Angola, ainda não estavam bem definidos. Sabia-se que o

\footnotetext{
${ }^{36}$ HENDERSON, A Igreja em Angola..., p. 102.

${ }^{37}$ HENDERSON, A Igreja em Angola..., p. 102.

${ }^{38}$ PÉLISSIER, Réne. História das Campanhas de Angola: resistências e revoltas (1845-1941) - vol. II. 2. ed. Lisboa: Editorial Estampa, 1997, p. 180-185.

${ }^{39}$ PÉLISSIER, História das Campanhas de Angola, vol. II, p. 185.
} 
espaço era uma zona comercial e de exploração de escravos de Portugal, que também era um espaço de atuação dos missionários católicos capuchinhos, mas também que ainda havia terras ainda desconhecidas e carentes de ações missionárias:

Os comerciantes insistiam em atuar na área fixada desde a costa do Loango até Ambriz, em 1845, mas, a fronteira norte de Angola era, teoricamente, na margem esquerda do M'Bridge, embora nenhuma enseada (Ambrizete, Mussera, Ambriz, etc) a sul da foz desse rio tivesse sido ocupada até o primeiro distrito português. [...] O limite marítimo meridional fixava-se, de maneira igualmente arbitrária, no Cabo Negro. No século XIX, ainda não se tinham atingido os rios (Zaire, Cenene) que servem de fronteira à Angola no século XX. $\mathrm{Na}$ parte interior, os limites de Angola eram dados pela influência do reino português na região, começando com os estados de Luanda e do Cassage. Quanto ao reino de Benguela, o rebordo oriental do planalto dos Ovimbundos e as extremas do Humbe a sul, bastavam aos apetites cartográficos do Portugal de então. ${ }^{40}$

Por outro lado, é importante destacar que esse avanço dos protestantes e católicos estrangeiros se devia à ausência de missionários católicos em várias regiões do interior de Angola, já que eles se concentravam mais em Luanda e outras capitais. Inclusive havia grande carência de missionários católicos mesmo nas áreas já ocupadas $e$ catequisadas desde o século XIX, favorecendo o expansionismo de missionários estrangeiros e protestantes. Para se ter uma ideia, em finais do século XIX, o poder do Manicongo (rei do Congo, região ao norte de Angola) era fictício, mas, sua posse era legitimada com o batismo católico. A cada novo soberano que assumia o poder local, os missionários que moravam em Luanda eram convocados para a cerimônia cristã que consagraria a investidura de cada Manicongo eleito. O número de missionários disponíveis para tais cerimônias era sempre um problema.

Já catequizados, os reis locais passavam a cobrar a presença de missionários para suas atividades sociais e políticas. Em 1804, por exemplo, Garcia V já reclamava a ausência de missionários às suas cerimônias. Os poucos missionários que atuavam em Angola naquele momento moravam em Luanda, havendo dificuldades de saída para outras regiões do interior. A situação era tal que Garcia $V$ teve que esperar até 1814 para que lhes enviassem um capuchinho. Em 1842 e 1843, Henrique II pediu um padre missionário e obteve a visita de um prelado africano que o coroou e ficou evangelizando no Congo até $1845^{41}$.

Foi entre as queixas e solicitações de missionários na região que o rei de Portugal prometeu restaurar as igrejas de S. Salvador e manter um missionário e um professor de ensino primário, além de prometer defender o Manicongo. Em troca, o rei do Congo lhe daria autorização para que portugueses se instalassem nas terras do

\footnotetext{
${ }^{40}$ PÉLISSIER, História das Campanhas de Angola, vol. II, p. 30-31.

${ }^{41}$ PÉLISSIER, História das Campanhas de Angola, vol. II, p. 56.
} 
Marquês de Mossul, espécie de vassalo do Manicongo. O contato deste rei com os portugueses, contudo, ficou limitado aos missionários capuchinhos. Segundo Réne Pélissier, este mesmo rei, aos 70 anos, confessaria ao Capitão António Joaquim de Castro que o visitava, que nunca vira brancos, a não ser os missionários capuchinhos ${ }^{42}$.

Na primeira metade do século XX, a presença de missionários católicos em Angola ainda era objeto de reivindicações como mediadores de conflitos locais, mas, já disputava atenção com os protestantes, que muitas vezes eram preferidos aos católicos. D. Pedro, marquês de Katende, por ocasião da morte de seu tio Henrique II, reclamou a presença de um missionário católico para o funeral de seu tio Henrique II e, na sequência, para sua coroação ante as disputas locais. Em resposta, Luanda remeteu logo dois missionários, via Ambriz e Bembe, com uma escolta de uns trinta homens sob o comando do chefe de Bembe Zacharias da Silva Cruz, para garantir a sucessão do marquês de Katende ante seu adversário D. Álvaro Dongo, que tinha mais prestígio popular. Entretanto, a presença dos missionários não resolveu, e o marquês de Katende terminou expulso de S. Salvador pelo rival, levando a comitiva dos padres católicos portugueses a fugirem do local, onde ainda predominava a disputa de poder. Desta forma, a capital de S. Salvador ficou fora da atuação de ordens religiosas e do domínio da administração portuguesa até meados de 1870 , favorecendo os protestantes ${ }^{43}$.

É neste clima acirrado, entre os representantes do colonialismo português (governadores, militares e comerciantes), os reis e os sobas (africanos que assumiam a administração de postos locais), que os missionários católicos e protestantes vão disputando espaços de atuação em Angola. O quadro de disputa entre eles se agrava com a deflagração da Primeira Guerra, entre 1914 a 1918, e o aprofundamento das revoltas internas, que contavam com a orientação de missionários protestantes para reagirem ao colonialismo português.

Entre o final do XIX e até o final da Guerra, ocorrem algumas revoltas e sublevações em Angola envolvendo missionários protestantes provenientes de outras nações, que eram acusados pelos portugueses de ensinar a bíblia nas línguas locais $e$ intermediar com a sua própria (inglês, alemão $e$ francês), em detrimento da língua portuguesa. E, segundo as queixas que vamos arrolando neste trabalho, para completar ainda contribuíam para acirrar os ânimos contra as formas administrativas portuguesas em torno dos usos do trabalho forçado e da cobrança de impostos.

Um exemplo de queixa da interferência dos missionários protestantes estrangeiros na política colonial portuguesa se pode perceber em novembro e dezembro de 1913, quando ocorre a "Revolta de Álvaro Buta", um soba (chefe local encarregado de arregimentar homens) que reagiu às cobranças de impostos $e$ às ordens de recrutar em torno de 1500 homens da terra para trabalhos em Cabinda e no Arquipélago de S. Tomé, por determinação das autoridades portuguesas. Segundo Réne Pélissier, a revolta que era uma "sedição antifiscal" tinha como consequência direta a ação $e$ o ensinamento dos missionários batistas que atuavam na região ${ }^{44}$.

\footnotetext{
${ }^{42}$ PÉLISSIER, História das Campanhas de Angola, vol. II, p. 56-57.

${ }^{43}$ PÉLISSIER, História das Campanhas de Angola, vol. II, p. 130-131.

${ }^{44}$ PÉLISSIER, História das Campanhas de Angola, vol. II, p. 300.
} 
Para Pélissier, a prova desta interferência tinha como base o fato de Álvaro Buta, ao se queixar da situação acusando o rei D. Manuel de "vender seu país aos portugueses" e intimá-lo "a restituir o dinheiro que recebera em troca dos infelizes que haviam sido exportados para a costa", sob pena de invadir S. Salvador com seus homens, estando, contudo, disposto a negociar a situação por intermediário do reverendo Bowskill, protestante membro da missão Batista em S. Salvador ${ }^{45}$. Tal fato era representativo do poder de influência que os protestantes estavam ganhando nas questões locais em detrimento do poder dos católicos.

Observe-se que Álvaro Buta havia negado qualquer diálogo com os dois padres católicos que lhes tinham sido oferecidos, preferindo dialogar com o reverendo da missão Batista. Em 06 de março de 1914, Buta seguia com suas rebeliões, gabandose de ter o apoio dos missionários protestantes ingleses. Entre janeiro e fevereiro de 1914, como resultado das revoltas, Cabinda estava quase toda queimada, com exceção das casas dos missionários batistas e de uma fortaleza portuguesa ${ }^{46}$.

Estas e outras interferências de missionários protestantes foram colocando os portugueses e missionários católicos contra os protestantes, que já tinham se tornado personagens indesejados. Um mês antes, em 19 de fevereiro de 1914, o governador interino de S. Salvador manda prender o rev. Bowskill, e seus auxiliares africanos, acusando-o de ser o instigador e fornecedor de pólvora aos rebeldes que atacavam os portugueses e suas instituições ${ }^{47}$.

Como já salientamos, Portugal estava na mira da comunidade internacional. Daí o caso não tardou a chegar nos jornais ingleses, que investiam em denúncias das permanentes práticas portuguesas de imposição do trabalho forçado entre os nativos, em contraposição aos seus discursos civilizatórios. Contudo, em setembro de 2014, os conflitos ainda persistiam entre Buta $e$ as autoridades, acrescida pela prisão dos missionários protestantes. Outro missionário batista, Carson Graham, ao regressar para Cabinda, tendo retornado da Inglaterra, se oferecia para intermediar novos acordos.

Desta vez, os acordos foram repelidos por Buta, que já não acreditava mais nos acordos para favorecer a dominação dos portugueses. Contudo, em começos de 1915, o missionário Carson Graham conseguiu intermediar o conflito, ganhando também muitos adeptos africanos. A situação desagradou mais ainda os portugueses. E, para ampliar as reações portuguesas, em julho de 2015, outro missionário batista, Simon Keke, procurava intermediar acordos entre Buta e a autoridade de S. Salvador. Em consequência, ele passou a ter sua residência na missão vigiada, terminando na prisão juntamente Buta ${ }^{48}$. A partir daí, abateu-se a perseguição aos protestantes e a repressão contra os jovens africanos que se recusassem a trabalhar $e$ a servir às autoridades portuguesas, principalmente nos trabalhos de carregadores ou de soldados que seguiam para o Sul de Angola.

\footnotetext{
${ }^{45}$ PÉLISSIER, História das Campanhas de Angola, vol. II, p. 300.

${ }^{46}$ PÉLISSIER, História das Campanhas de Angola, vol. II, p. 301-302.

${ }^{47}$ PÉLISSIER, História das Campanhas de Angola, vol. II, p. 305.

${ }^{48}$ PÉLISSIER, História das Campanhas de Angola, vol. II, p. 313.
} 


\section{A atuação das missões no salazarismo}

Como vímos observando, as situações das missões católicas e protestantes vão mudando de acordo com os acordos políticos entre a Igreja católica e o Estado e com as questões locais e suas relações com os protestantes. Num primeiro momento, observa-se a situação precária das missões católicas entre meados do XIX até fins da Primeira República, em 1926, seguida de uma nova sintonia com o Estado através dos Acordos Missionários estabelecidos com o regime Salazarista, de base católicanacionalista, depois de 1940 até 1975.

Disto decorre, conforme veremos, uma ação missionária portuguesa em Angola pautada no projeto de cristianização dos nativos e na educação colonial para o trabalho, em cumprimento da missão civilizadora de conhecimento e reformulação da cultura nativa em cultura civilizadora do trabalho. A atuação dos missionários católicos e protestantes, ainda que com algumas diversidades, entre o XIX e a I República, não deixam de cumprir o projeto de missão educativa e civilizadora do nativo. Com a ascensão do salazarismo, a Igreja católica assume uma nova posição frente às missões protestantes, ganhando novos privilégios.

À primeira vista, há relativa impressão de que Salazar e os Católicos andavam de mãos dadas. Entretanto, é preciso considerar que estas relações não eram tão harmônicas quanto se costuma pensar, para que se possa compreender porque católicos e protestantes atuavam nos espaços coloniais, ainda que estabelecesse acordos que de certa maneira beneficiavam as missões católicas. Ao assumir o poder, Oliveira Salazar impõe limites ao poder da Igreja, quebrando com expectativas católicas de que, como ex-líder do Centro Católico, colocaria a Igreja à frente de seu regime de governo, conhecido como salazarismo.

Sobre isso, Rita Maria Cristovam Cipriano Almeida de Carvalho destaca um trecho que nos permite visualizar o complexo das relações de Oliveira Salazar com a Igreja Católica portuguesa:

Salazar torna-se Presidente do Conselho a 4 de Julho de 1932. Nada do que acontece a seguir indicia uma vontade de alterar o quadro legal herdado da Ditadura Militar em matéria de relações entre o Estado e a Igreja. [...]

Quando, a 27 de Abril de 1928, António Oliveira Salazar entra para o Governo liderado por Vicente de Freitas dirá aos católicos que esperava que estes fossem os primeiros a fazer os sacrifícios que lhes pedisse e os últimos a pedir os favores que ele não lhes podia fazer. Pouco tempo depois apresenta como a primeira prioridade do Executivo o 'equilíbrio das contas públicas'. A definição do regime jurídico das relações entre o Estado e a Igreja Católica não constituía, naquele momento, matéria prioritária. O desenrolar da 'crise dos sinos', que atrás descrevemos, atesta-o bem. ${ }^{49}$

${ }^{49}$ CARVALHO, Rita Maria Cristovam Cipriano Almeida de. A Concordata de Salazar: Portugal-Santa Sé (1940). Tese (Doutorado em História Contemporânea Institucional e Política de Portugal). Universidade Nova de Lisboa. Lisboa, 2009, p. 77-79. 
As reações não tardariam por parte dos representantes da Igreja. Assim, Joaquim Dinis da Fonseca, tido como reputado dirigente católico, dirigiu uma carta a Salazar, opondo-se às suas formas de governar, excluindo os serviços de pessoas ligadas à Igreja. Entretanto, apesar dos descontentamentos de membros da Igreja, Salazar chegou a manter um entendimento cordial e até de favoritismo com a Igreja católica, dialogando cotidianamente com seus representantes, ao longo da década de 1930. Em 1940, chegaram a acordos comuns, com a apresentação de um texto final sobre os Acordos Missionários e da Concordata, cujas negociações haviam começado em 1937, quando o Cardeal Patriarca Cerejeira entregou a Salazar o anteprojeto da Concordata redigido pela Santa Sé. Mas, nem tudo era harmonia. O anteprojeto foi acompanhado de muitas discussões, ao longo da década de 1930, envolvendo Salazar, Cerejeira, intelectuais católicos e doutrinadores do regime. Desta forma, o Acordo Missionário só se concretiza em abril de 1940, quando Salazar divulga nos jornais o texto que foi corrigido com apoio de Dinis da Fonseca, antigo crítico de seu governo em relação à Igreja Católica.

Em 16 de dezembro de 1945, a Santa Sé entrou em contato com o Governo Português para fixar os Acordos Missionários. No ato, a Igreja ficou comprometida de enviar mais de "uma centena de missionários estrangeiros para as colônias portuguesas". Entretanto, em pouco tempo, os missionários portugueses aparecem se queixado com o Governo português, visto que este reduz para "três quartos do número dos missionários portugueses e o numero de missionários estrangeiros em cada diocese", resultado da decisão do Ministro das Colônias. Pelo referido relatório, comentasse que Marcelo Caetano estava ciente de que a quantidade da populacão de Luanda é de 1.509.979, sendo a população católica em torno de 414.000. Enquanto o número de padres seria de 20 padres portugueses seculares e 23 padres do Espírito Santo, perfazendo um total de 43 padres católicos portugueses contra 26 estrangeiros ${ }^{50}$.

Noutro relatório, Silva Pôrto informa que a população era de 943.529 , sendo 53.300 católicos e 63.258 protestantes. Frente a eles atuavam, 24 padres católicos portugueses contra 22 estrangeiros (envolvendo alemães, belgas, holandeses $e$ franceses). Em Nova Lisboa o número da população era muito superior ao número de católicos e protestantes: de 1.284.394, 369.490 eram católicos e 90.000 eram protestantes. O que era citado como uma preocupação pelos Bispos que atuavam na missionação nas colônias e que também defendiam, em outubro de 1946, a necessidade de manter os missionários estrangeiros, considerado grande o número de nativos não cristãos:

Principalmente, em Nova Lisboa que precisava muito de 100 missionários novos, para dividir cristandades já com 30, 40, 50 mil cristãos e fundar missões novas em regiões ainda não ocupadas; o que convinha não era fechar a porta para o número de estrangeiros, mas sim arranjar sacerdotes

50 "Restrições à entrada de missionários católicos estrangeiros nas Colónias portuguesas". Cf. PT-TTAOS-D-N3-5-18 m0003.TIF - acesso em Doc.: PT-TT-AOS-D-N-3-5-18. Disponível em:<http://digitarq.arquivos.pt/ViewerForm.aspx?id=3896305> . Acesso em: 08 jul. 2015. 
seculares (que mais predominava) que se ocupassem da população branca, a mais numerosa, e que estimariam ter um padre português. Já nas missões propriamente ditas é menos importante a questão da nacionalidade dos missionários. $O$ importante é que o missionário tenha um zelo que não ofenda interesses nacionais, dos missionários do Espírito Santo, particularmente, [...] nada se pode temer a respeito da nacionalidade portuguesa, com prova de um passado de mais de meio século de evangelização entretida quase só por estrangeiros, que defenderam os interesses de Portugal através do Sertão como se portuguesa for a sua natural nacionalidade. $^{51}$

Em seguida ele comenta o crescimento das missões protestantes, como "as missões que ainda se pode pensar o bem dos indígenas", principalmente, o ensino rudimentar (que consistia em falar, ler e escrever português), que foi conferido ao Estatuto Missionário católico que não conseguiu dar conta.

Já o Ministro das Colônias tinha como principal preocupação a missionação nas mãos de estrangeiros e a falta de contato na língua portuguesa com os indígenas, o que significava um perigo para os domínios de Portugal em África. Também demonstrava preocupação em manter o 'Acordo Missionário', conforme se lê no documento que emite em 26 de novembro de 1946, informando dos interesses do governo em manter o trabalho de missionação nas colônias, e lembrando que a Santa Sé atuava no interesse do Governo português. O que não se permitia a rigidez de estabelecer um quantitativo para a ação missionária. Assim era

[...] inútil e até inconveniente estabelecer limitação aplicável indiscriminadamente todas circunscrições [...] e que as circunstancias eram bem diferentes entre Cabo Verde, Guiné, São Tomé, Luanda, Nova Lisboa, Silva Pôrto, Lourenço Marques, Beira, Nampula e Timor - entre janeiro de 1947 e janeiro de $1949 .^{52}$

O que nos leva a perceber que ainda havia uma força religiosa local muito presente ao longo do colonialismo dos anos 1940-50. Estas diferenças também aparecem em São Tomé e Príncipe e na Guiné Portuguesa, com números menores da população, dos católicos e dos protestantes. O Relatório também nos informa o "Movimento dos Protestantes na Província de Angola", com 245 missionários (todos estrangeiros). 12 médicos; 3.000 auxiliares; 20 enfermeiras. 103 auxiliares de enfermarias. Escolas (todas dirigidas por estrangeiros) 1.050, com alunos portugueses,

51 "Restrições à entrada de missionários católicos estrangeiros nas Colónias portuguesas". Cf. PT-TTAOS-D-N3-5-18 m0003.TIF - acesso em Doc.: PT-TT-AOS-D-N-3-5-18. Disponível em: <http://digitarq.arquivos.pt/ViewerForm.aspx?id=3896305>. Acesso em: 08 jul. 2015.

52 Cf. MATHIAS, Marcelo (Diretor Geral). "A Bem da Nação". Doc. 0031 a 0035 . Arquivo da Torre do Tombo. 
mas educados por estrangeiros: 47.000; "Movimento Protestante em Moçambique": missionários - 90, auxiliares 348 (estrangeiros e portugueses), Missões 14, Filiais $35^{53}$.

$\mathrm{O}$ que se tem de mudanças com o Acordo Missionário em relação às missões em Angola, é a ampliação da percepção da necessidade de se ampliar e promover o clero nativo. Entretanto, esta nova arregimentação dos nativos para as missões que assumiam novos trabalhos, principalmente com a criação dos novos seminários, perante o Estado não era tão simples, diz que até foi um processo bem lento ${ }^{54}$. Em relação às queixas da exploração do trabalho forçado, esta acompanha todo o século $\mathrm{XX}$ até o fim do império português.

Sobre isto, é importante considerar que as fontes e referências sobre as práticas de católicos e protestantes indicam formas diferentes de atuar e missionar, que sugerem a necessidade de um trabalho mais aprofundado sobre estas questões, já que neste trabalho a meta foi apontar alguns aspectos da complexa situação das missões católicas e protestantes em Angola, entre o XIX e a primeira metade do XX.

\section{$\operatorname{soc} 8$}

\section{RESUMO}

Este trabalho pretende discutir algumas práticas educativas e civilizatórias implementadas pelas missões católicas e protestantes em contraposição ao que era determinado pela política educativa do Estado português, particularmente nos espaços rurais e naqueles ainda não ocupados pelos portugueses, ainda que estivessem sob sua concessão.

Palavras Chave: Colonialismo; Política Educativa; Missões.

\begin{abstract}
This paper aims to discuss some educatives and civilizatorys practices implemented by catholic and protestant missions as opposed to what was determined by the educative politic of the portuguese State, particularly in rural areas and in those not yet occupied by the portuguese, even though they were under concession.
\end{abstract}

Keywords: Colonialism; Educative Polits; Missionarism.

Artigo recebido em 07 ago. 2016.

Aprovado em 29 out. 2016.

53 "Restrições à entrada de missionários católicos estrangeiros nas Colónias portuguesas". Cf. PT-TTAOS-D-N3-5-18 m0003.TIF - acesso em Doc.: PT-TT-AOS-D-N-3-5-18. Disponível em: $<$ http://digitarq.arquivos.pt/ViewerForm.aspx?id=3896305 > . Acesso em: 08 jul. 2015.

54 TANGA, Lino. O Impacto da Concordata e do Acordo Missionário em Angola (1940-1975). Tese (Doutorado em Teologia Histórica). Universidade Católica Portuguesa. Lisboa, 2012, p. 63-64. 